\title{
Morphometric of the interface of the central retina in patients with retinal vein occlusion
}

\author{
Índices morfométricos da interface da retina central \\ em pacientes com oclusão da veia retiniana
}

Mukharram Bikbov¹, Rinat Fayzrakhmanov², Timur Gilmanshin², Inga Gilyazova²

\begin{abstract}
$\underline{\text { ABSTRACT }}$
Background: Systematization of characteristics and morphological changes in the retina, and understanding its role in occlusive diseases involving retinal vessels can contribute to research on the dynamic of the pathological process and to improved understanding of disease treatment. Objective: To research the basic morphometric and structural indicators of the macular region of the retina in patients with central retinal vein occlusion (CRVO). Settings and Design: Ufa Eye Research Institute, retrospective case series. Methods: The basic morphometric and structural indices of the macular region of the retina in 15 patients with CRVO were studied using the optical coherence tomography. Patients with CRVO (15 eyes) were included in Group I (study), and 10 patients with no retinal pathology (10 eyes) were included in Group II (control). Statistical analysis used: For the statistical analysis, the Statistica 6.1 program was used with a parametric method, the Student's test. To consider the probability of statistically significant differences, values beginning with up to $p<0.05$ were accepted. Results: In Group II, we determined the correct profile of the macula with fovea centralis and a range of retinal thickness from $221.4 \pm 10.97$ to $355.2 \pm 12.17 \mu \mathrm{m}$, with an average value of $-299.01 \pm 7.56 \mu \mathrm{m}$. In Group I mean retinal thickness at all points of the study area ranged from $247.86 \pm 39.06$ to $494.07 \pm 40.22 \mu \mathrm{m}$ with a gradual thickening of the periphery to the center, reaching a maximum at a distance of $893 \mu \mathrm{m}$ from the center of the fovea. The average thickness of the retina as a result of edema increased by a multiple of 1.3 and amounted to $-386.97 \pm 16.26 \mu \mathrm{m}$. Conclusions: The study indicated that the edema is the main morphological substrate, promoting structural changes in the central retina in retinal vein occlusion, and is cystic in nature. Increase in total retinal thickness (up to $386.97 \pm 16.26 \mu \mathrm{m}$ ) in this pathology is largely due to the structural changes in zones, covering the îter plexiform layer - the inner nuclear layer and the nerve fiber layer with the inner limiting membrane. Meanwhile a significant increase in the thickness of the outer plexiform with the inner nuclear layers (up to 94.94 $\pm 5.08 \mu \mathrm{m}$ ) and nerve fiber layers (up to $54.6 \pm 3.26 \mu \mathrm{m}$ ) was observed.
\end{abstract}

Keywords: Thrombosis; Retinal vein occlusion; Macular edema; Tomography, optical coherence

\footnotetext{
1 Ufa Eye Research Institute, Ufa, Russia.

${ }^{2}$ Vitreoretinal and Laser Surgery Department, Ufa Eye Research Institute, Ufa, Russia.

Study carried out at the Ufa Eye Research Institute, Ufa, Russia.

The authors declare no conflicts of interests.

Received for publication 12/08/2015 - Accepted for publication 16/01/2016
}

Rev Bras Oftalmol. 2016; 75 (2): 127-31 


\section{ResUMO}

Introdução: Sistematização característica e alterações morfológicas na retina, compreensão de sua arquitetura em doenças oclusivas de vasos retinianos para contribuir com a melhoria dos estudos sobre as regularidades da dinâmica do processo patológico, diagnóstico e tratamento da doença. Objetivo: Investigar a morfometria de base e indicadores estruturais da região macular da retina em pacientes com oclusão da veia central da retina (CRVO). Definições e design: Ufa Eye Research Institute, série de casos retrospectiva. Métodos: A análise morfométrica de base e índices estruturais da região macular da retina em quinze pacientes com CRVO. Foram estudados pacientes com CRVO (15 olhos), incluídos no Grupo I (em estudo), 10 pacientes com qualquer patologia da retina (10 olhos), incluídos no Grupo II (controle), com o uso da tomografia de coerência óptica. Para a análise estatística utilizou-se o programa Statistica 6.1 usando o método paramétrico - teste de Student. A probabilidade de diferenças estatisticamente significativas foram valores começando com até $\mathrm{p}<0,05$. Resultados: No Grupo II, o perfil correcto da mácula com fovea centralis e uma gama de espessura da retina de $221,4 \pm 10,97$ a $355,2 \pm$ $12,17 \mu \mathrm{m}$, com um valor médio de - 299,01 \pm 7,56 $\mu \mathrm{m}$ foram determinadas. No Grupo I, a espessura média da retina em todos os pontos da área de estudo variou de $247.86 \pm 39.06$ a 494,07 \pm 40,22 $\mu \mathrm{m}$ com um espessamento gradual da periferia para o centro, atingindo um máximo em um raio de $893 \mu \mathrm{m}$ a partir do centro da fóvea. A espessura média da retina, como resultado do edema aumentado em 1,3 vezes e elevouse a $-386,97 \pm 16,26 \mu \mathrm{m}$. Conclusões: O estudo indicou que o edema é cístic por natureza e é o principal substrato morfológico responsável por mudanças estruturais que promovem a oclusão da veia central da retina. O aumento na espessura total da retina (de $386.97 \pm 16.26 \mu \mathrm{m})$ nesta patologia deve-se às mudanças estruturais nas zonas que vão da camada plexiforme - nucleo interno, camada de fibras do nervo óptico e membrana limitante Foi observado ainda um aumento significativo da esessura do plexiforme externo com cas camadas nucleaes internas (de $94.94 \pm 5.08 \mu \mathrm{m}$ ) e camadas de fibras do nervo óptico (de $54.6 \pm 3.26 \mu \mathrm{m}$ ).

Descritores: Trombose; Oclusão da veia retiniana; Edema macular; Tomografia por coerência óptica

\section{INTRODUCTION}

A cute impairment of circulation in the vessels of the reti na is an example of severe pathology of the vision which leads to a rapid and often irreversible loss of visual function and is one of the major causes of blindness ${ }^{(1)}$

Among diseases of the retina and optic nerve, the prevalence rate of vascular lesions is $41.6-54.9 \%{ }^{(2)}$. Thrombosis of the central retinal vein (CRVO) and its branches (BRVO) in the structure of vascular pathology in the incidence, severity of lesions and functional prognosis are, after diabetic retinopathy, the second most common cause of partial or complete loss of vision. ${ }^{(2,3)}$

Systematization of characteristics and morphological changes in the retina, and understanding its role in occlusive diseases involving retinal vessels can contribute to research on the dynamic of the pathological process and to improved understanding of disease treatment. Optical coherence tomography (OCT) is, to date, the best method of objective diagnostic, since its use makes it possible not only to evaluate objectively the thickness of the retina, but also to visualize the vitreoretinal structure. ${ }^{(4,5)}$

In the modern scientific literature, there are few reports on the results of OCT studies in patients with CRV occlusion and its branches ${ }^{(6-8)}$, but there are no quantitative data on the retinal layer changes in this disease.

\section{Methods}

15 patients ( 15 eyes) with newly diagnosed retinal vein occlusion, observed in 2014, were selected by random sampling technique. The duration of the disease from the specific complaint until examination ranged from two weeks to six months. Patients had not received special treatment by the time of the examination. Patients with concomitant diseases of the retina were not included in the study.

Patients with retinal vein occlusion (15 eyes) were included in Group I (study), 10 patients with no retinal pathology (10 eyes) were included in Group II (control). The demographic and clinical characteristics of these patients are presented in Table 1

Table 1

\section{Demographic and clinical characteristics}

\begin{tabular}{lcc}
\hline Demographic variable & Group I (study) & Group II (control) \\
\hline Gender & & $7(56.7 \%)$ \\
Male & $8(53.3 \%)$ & $6(60.0 \%)$ \\
Female & $4(40.0 \%)$ & $62.3 \pm 1,850-75$ \\
Age at visitMean \pm SDRange & $60.8 \pm 2.147-71$ & $8(53.3)$ \\
\hline Distribution by age (count, $\%)$ & $2(13.3)$ & $1(10.0)$ \\
$<45$ & $5(33.3)$ & $3(30.0)$ \\
$45-<65$ & $6(60.0)$ & $10(67.7)$ \\
$\geq 65$ & $5(33.3)$ & $6(60.0)$ \\
\hline Eye involvement (count, \%) & $4(40.0)$ & $0(0)$ \\
Right eye & $0(0)$ & \\
Left eye & & \\
Both eyes & & \\
\hline
\end{tabular}


Table 2

The thickness of the retina morphological structures

\begin{tabular}{clcc}
\hline Layered zones of the retina & Group I (study) & Group II (control) \\
\cline { 1 - 2 } Zones & \multicolumn{1}{c}{ Total thickness } & $386.97 \pm 16.26^{* *}$ & $299.01 \pm 7.56$ \\
\cline { 1 - 2 } 2 & Pigment epithelium - outer segments of photoreceptors & $63.26 \pm 1.01^{* *}$ & $72.15 \pm 0.81$ \\
2 & Inner segments of photoreceptors - the outer nuclear layer & $85.78 \pm 4,48$ & $76.77 \pm 2.93$ \\
3 & Outer plexiform layer - The inner nuclear layer & $94.94 \pm 5.08^{* *}$ & $62.11 \pm 4.08$ \\
4 & Inner plexiform layer - Layer of ganglion cells & $88.05 \pm 5.54^{*}$ & $69.82 \pm 4.23$ \\
5 & Nerve fiber layer - Inner limiting membrane & $54.6 \pm 3.26^{* *}$ & $13.76 \pm 1.4$ \\
\hline
\end{tabular}

* - Significant difference compared with the control group $(\mathrm{p}<0.05)$, ** - $\mathrm{p}<0.001$

Only those patients who had a definite diagnosis of CRVO were included regardless of type of disease (ishemic and nonishemic).

All patients with other retinopathies mimicking CRVO, îr with any other retinal lesion or any other factor (e.g., cataract) including any treatment for CRVO and those who had had the disease for more than six months were excluded.

Standard ophthalmic examination included ophthalmobiomicroscopy with the use of an aspheric lens (78 D, OCT) of the macular region by RetinaScan - 3000 (NIDEK) tomography, Macular Multi Cross mode. The data were evaluated according to the average horizontal plane with the capture of the study field in $6 \mathrm{~mm}(6000$ $\mu \mathrm{m})$, the center of which was the foveola (the focal point). Registration of parameters under study was carried out using tomography software for automatic differentiation of boundaries and analysis of retinal areas thickness, combining several layers.

In the test and control groups of patients, we estimated total retinal thickness and retinal area thickness at 21 points by given plane with the 300 microns step. For convenience, we identified these areas of the retina using numerals (Table 2).

The study was conducted in accordance with the World Medical Association Code of Ethics (Declaration of Helsinki on Patient Safety). The research protocol of this study was approved by the local Ethics Committee Institution. The study protocol was approved by the institutional review board and all participants provided written informed consent.

\section{RESULTS}

The following characteristics of edema changes in the macular area were observed ophthalmoscopically in all patients of Group I: dimness of edematous area, turbidity of the retina, disappearance of the reflex, radial striations, and blurring of macula vessels and the peripapillary zone. In addition, macula protrusion was visualized.

In Group II, the correct profile of the macula with fovea centralis and a range of retinal thickness from $221.4 \pm 10.97$ to $355.2 \pm 12.17 \mu \mathrm{m}$, with an average value of $-299.01 \pm 7.56 \mu \mathrm{m}$ were determined. In Group I mean retinal thickness at all points of the study area ranged from $247.86 \pm 39.06$ to $494.07 \pm 40.22 \mu \mathrm{m}$ with a gradual thickening of the periphery to the center, reaching a maximum at a distance of $893 \mu \mathrm{m}$ from the center of the fovea. The average thickness of the retina as a result of edema increased by a multiple of 1.3 and amounted to $-386.97 \pm 16.26 \mu \mathrm{m}$.
As shown in Table 2, the total thickness of the retina in patients from Group I (study) was significantly greater than for patients in Group II (control) $(\mathrm{p}<0.001)$. Differences in the average thickness of the fourth layered zone of the retina were significant $(\mathrm{p}<0.05)$ in patients from both Groups I and II, and highly significant $(\mathrm{p}<0.001)$ in zones 1,3 and 5 . It should be noted that there was a 1.5 fold increase in the thickness of the 3 zones covering the outer plexiform and the inner nuclear layer and a fourfold increase in the fifth zone comprising a layer of nerve fiber and the inner limiting membrane in patients from Group I.

Central area changes in retinal vein occlusion are associated not only with a thickening of the zones of the retina, but also with changes in its structural characteristics. OCT-changes that were visualized in this pathology are the result of a reduction in the intensity of the intra-retinal reflection and decreased diffusion due to an accumulation of fluid, along wiht cystic changes, thereby increasing the thickness of the retina and changes of its contour. The diffusion decrease is the most obvious in the middle layers, where there is the most concentration of the liquid. At the same time, morphological changes are accompanied with "spongy" thickening of the retina and cystic changes. All received tomograms clearly show changes specific to the pathology in the form of the presence of fluid-filled cells in different retinal layers, namely pseudocysts that are mainly located in the outer plexiform and inner nuclear layers of the retina, which explains the thickening of the zone in the retinal vein occlusion. There was one case $(6.7 \%)$ of fluid accumulation mainly in the outer layers of the retina with detachment of the neuroepithelium and an increase in optical density of internal layers, namely diffuse edema of the macular area. All patients showed thinning of the photoreceptor layer with pigment epithelium atrophy of various degrees of intensity.

Of particular note is the discontinuous spread of edema at various points of the study plane with maximum values of the retinal thickness at the fovea.

Data analysis of the thickness of the 3rd and 5th zones of the foveola in patients from Group I showed a significant increase up to $102.79 \pm 24.89$ and $35.92 \pm 11.01 \mu \mathrm{m}$, and relatively normal levels in Group II, corresponding to $4.0 \pm 1.27$ and $0.8 \pm$ $0.8 \mu \mathrm{m}(\mathrm{p}<0.01)$. Thus, zone thickness covering the outer plexiform and the inner nuclear layers, increased 25 fold in the foveal region in patients with retinal vein occlusion, and by 45 fold in the area including the nerve fiber layer and an inner limiting membrane. 
Dome-shaped elevation was noted in the third zone with a maximum of $131 \pm 17.11 \mu \mathrm{m}$ in the fovea (spaced at 900 microns from the foveola). The morphological changes are contributed by structural features of the fovea, where the greatest number of cysts had formed, the largest of which are located directly in the foveola.

There is a significant uneven increase in structures with a pronounced inhomogeneity of the profile in the study of the 5th zone.

\section{Discussion}

Retinal diseases are always accompanied by characteristic structural changes in tissues with different pathologies, the identification of which represents an integral part of any retinological study. The growth of technology has contributed to improving the diagnosis of retinal changes under the influence of various internal and external factors on eyesight. Thus, the optical coherence tomography of the retina, first used in ophthalmology in 1995 by the American scientist, Carmen A. Puliafito, became, almost directly after its first appearance, the "gold standard" in retinological research. The detection of subtle structural features of the retina provides a more complete and clear understanding of the transformation of retinal tissue in diseases of the posterior segment of the eyeball, monitoring the development and course of pathological processes, controlling treatment of the disease and predicting the outcome of the pathological process including for different types of surgical procedures. In addition, a detailed lamina analysis of retinal changes makes it possible to see the features of a pathological process in a new light, even in the midst of making improvements in the treatment of this condition. In this way, studies of the structure of the retina in age-related macular degeneration that were conducted earlier by our research group have, for the first time, highlighted clearly distinct features of different types of chorioretinal neovascular membranes in this pathology. This serves as a basis to propose a procedure for a differentiated approach to the treatment of these patients. ${ }^{(7)}$

The results of this study dedicated to morphometric indices of the central retinal zone interface in patients with retinal vein thrombosis testify to the thickness change of the central area of the retina caused by edema, the macular interface change, and varying degrees of involvement of different retinal layers in the pathological process.

This study confirms an increase in the average thickness of the retina and the macula shape in this pathology. Changes in thickness and shape of the central segment of the retina in occlusive processes in the central retinal vein and its tributaries are described in other studies that address this issue. ${ }^{(9-12)}$ This paper describes a $30 \%$ increase in average thickness of the macular area of the retina to $386.97 \pm 16.26$ microns with the highest index in the center corresponding approximately to the results presented by other authors with a similar index of 416 microns at average indices of the central part, and a thickness from 552 microns to $150 \pm 668.18 \pm 245.58$ microns. ${ }^{(9)}$

According to the authors of the paper, the changes in the macula in the retina vein thrombosis affect the outer plexiform layer, the inner nuclear layer and the retinal nerve fiber layer with the internal limiting membrane. It is obvious that these characteristic manifestations are a morphological marker of changes associated with retinal vein thrombosis. It is most likely that these changes are a consequence of disturbed organ/tissue circulation in vascular occlusion. Information relating to the complete layer analysis of retinal zones at a given condition are absent in references. Some works on the matter are devoted to describing the structural changes in the outer and inner segments of photoreceptors (inner segment/outer segment, IS/OS). ${ }^{(13)}$

The results obtained should contribute to the development of further clinical research in the field of occlusive vascular disorders of the retina. Due to the lack of other similar studies globally on the subject this study is considered to be both timely and relevant.

\section{Conclusion}

The use of optical coherence tomography provides a detailed assessment of the retinal peculiarities in patients with retinal vein occlusion.

Edema is a major morphological substrate contributing to the structural changes of the central area of the retina in retinal vein occlusion, and is cystic in nature.

An increase in the total thickness of the retina in this disease is largely due to the change of the thickness and structure of the retina areas, covering the outer plexiform, the inner nuclear layers and the nerve fiber layer with the inner limiting membrane.

The specific morphological changes of the layers of the central zone of the retina are other important diagnostic criteria of retinal vein occlusion that determine the choice of further treatment strategies.

\section{ACKNOWLEDGEMENTS}

This research received no specific grant from any funding agency in the public, commercial, or nonprofit sectors.

\section{ReFERENCES}

1. Katznelson LA, Forofonova TI, Bunin AY. Vascular diseases of the eye. Moscow: Medicine; 1990. 270 p.

2. Tankovskiy VE. Retinal vein thrombosis. Moscow: Voenizdat; 2000. $262 \mathrm{p}$.

3. Tultseva SN, Astakhov YS. Retinal vein occlusion (etiology, pathogenesis, clinical features, diagnosis, treatment). St. Petersburg: NL Publisher; 2010. 112 p.

4. Jackson TL, Nicod E, Angelis A, Grimaccia F, Prevost AT, Simpson AR, Kanavos P. Vitreous attachment in age-related macular degeneration, diabetic macular edema, and retinal vein occlusion: a systematic review and metaanalysis. Retina. 2013:33(6);1099-108.

5. Varano M, Scassa C, Ripandelli G, Capaldo N. New diagnostic tools for macular edema. Doc Ophthalmol 1999:97(3-4);373-9.

6. Bikbov MM, Fayzrakhmanov RR, Yarmukhametova AL, Gil'manshin TR. Features indicators of tonometry after macular surgery in patients with gas tamponade of vitreous cavity. Volgograd State Med Univ Bull. 2013:48;37-8.

7. Bikbov MM, Fayzrakhmanov RR, Yarmukhametova AL. Agerelated macular degeneration. Moscow; 2013. 196 p.

8. Fayzrakhmanov RR, Yarmukhametova AL, Gil'manshin TR Functional parameters after removal of fibrovascular membranes. Volgograd State Med Univ Bull. 2013;48:171-3. 
9. Ip MS, Gottlieb JL, Kahana A, Scott IU, Altaweel MM, Blodi BA, et al.. Intravitreal triamcinolone for the treatment of macular edema associated with central retinal vein occlusion. Arch Ophthalmol. 2004;122(8):1131-6.

10. Lin JM, Chiu YT, Hung PT, Tsai YY. Early treatment of severe cystoid macular edema in central retinal vein occlusion with posterior sub-tenon triamcinolone acetonide. Retina. 2007;27(2):180-9.

11. Rouvas A, Petrou P, Ntouraki A, Douvali M, Ladas I, Vergados I.. Intravitreal ranibizumab (Lucentis) for branch retinal vein occlusion-induced macular edema: nine-month results of a prospective study. Retina. 2010;30(6):893-902.

12. Spaide RF, Chang LK, Klancnik JM, Yannuzzi LA, Sorenson J, Slakter JS, et al. Prospective study of intravitreal ranibizumab as a treatment for decreased visual acuity secondary to central retinal vein occlusion. Am J Ophthalmol. 2009;147(2):298-306.

13. Ota M, Tsujikawa A, Kita M, Miyamoto K, Sakamoto A, Yamaike $\mathrm{N}$, et al. Integrity of foveal photoreceptor layer in central retinal vein occlusion. Retina. 2008;28(10):1502-8.

\section{Corresponding author:}

Rinat R. Fayzrakhmanov, MD, Phd, Ufa Eye Research Institute Pushkin str. 90, Ufa 450008, Russia.

Tel/fax +7(347)272-65-62, +7(347) 272-08-52, +7(347) 27237-75, Tel +7 (987) 6095585

\section{ERRATA}

Edição de março/abril 2016 , Vol. 75 ( 2 ) , pág.127-31 The original article "Morphometric of the interface of the central retina in patients with retinal vein occlusion" publicado na edição de março/abril da Revista Brasileira de Oftalmologia (Rev Bras Oftalmol 2016; 75 (2): 127-31), sofreu correção nos nomes dos autores. Os nomes dos autores corretos são: "Mukharram Bikbov (Bikbov M.), Rinat Fayzrakhmanov (Fayzrakhmanov R.), Timur Gilmanshin (Gilmanshin T.), Inga Gilyazova (Gilyazova I.)”. 